\title{
Gamification as a basic tool in distance education
}

\section{La Gamificación como herramienta básica en la educación a distancia}

\author{
ESCAMILLA, Regis Daisy†** \& MARTÍNEZ, Bahena Elizabeth \\ Tecnológico de Estudios Superiores de Cuautitlán Izcalli, Mexico \\ ID $1^{\text {st }}$ Author: Regis Daisy, Escamilla \\ ID $1^{\text {st }}$ Co-author: Bahena Elizabeth, Martínez / ORC ID: 0000-0003-4021-4866
}

DOI: $10.35429 /$ JCT.2020.12.4.17.23

Received: January 20, 2020; Accepted June 30, 2020

Abstract

"The use of mechanisms, aesthetics and the use of thought, to attract people, encourage action, promote learning and solve problems" (Karl. M. Kapp (2012), Zichermann \& Cunnigan).

Currently there are various teaching-learning strategies, which are useful and can be implemented according to the objective that is had with the group of students, it is there, where gamification is implemented, whose main objective is to influence behavior of people, since it can be a motivator to continue experimenting with new learnings, which lead the student to solve problems through games, having an assignment of points or feedback, as a result of it, and with it taking gamification as a basic tool in distance education

Objectives, methodology. Through this research, it is sought to demonstrate that within distance education there are various strategies that can be implemented in the material that makes up each subject, but this time we wanted to focus on gamification as a tool that can be implemented in the designs of Each of the materials of the distance subjects, so that, with this, it can be seen as another motivational alternative, so that the student becomes even more integrated in the training process of their learning.

Contribution. This research aims to demonstrate that gamification tools can be basic in the teaching-learning process of distance education, since this is where it is required that the student be motivated and generate a greater commitment in the process of their learning. The results of implementing gamification in distance education subjects bring us beneficial results in the implementation, thus having significant changes for the students, thus better professionals.

Gamification, Feedback, Basic tool, Distance education, Learning, Strategy
Resumen

"La utilización de mecanismos, la estética y el uso del pensamiento, para atraer a las personas, incitar a la acción, promover el aprendizaje y resolver problemas" (Karl. M. Kapp (2012), Zichermann y Cunnigan).

En la actualidad existen diversas estrategias enseñanzaaprendizaje, las cuales son útiles y se pueden implementar de acuerdo al objetivo que se tenga con el grupo de estudiantes, es ahí, donde se implementa la gamificación, la cual tiene como objetivo principal influir en el comportamiento de las personas, ya que puede ser un motivante para seguir experimentando con nuevos aprendizajes, que lleven al estudiante a la resolución de problemas por medio del juego, teniendo una asignación de puntos o bien un feedback, como resultado de la misma, y con ello tomando a la gamificación como herramienta básica en la educación a distancia.

Objetivos, metodología. Mediante esta investigación, se busca demostrar que dentro de la educación a distancia existen diversas estrategias que se pueden implementar en el material que conforma cada materia, pero en esta ocasión se quizo enfocar a la gamificación como una herramienta que se puede implementar en los diseños de cada uno de los materiales de las materias a distancia, para que, con ello, se pueda ver como una alternativa más de motivación, para que, el estudiante se integre aún más en el proceso de formación de su aprendizaje.

Contribución. Esta investigación, tiene como objetivo demostrar que las herramientas de gamificación pueden ser básicas en el proceso enseñanza-aprendizaje de la educación a distancia, ya que, es aquí donde se requiere que, al estudiante se le motive y genere un compromiso mayor en el proceso de su aprendizaje. Los resultados de implementar gamificación en las materias de educación a distancia nos traen beneficos resultados en la implementación, teniendo así cambios significativos para los estudiantes, formato así mejores profesionistas.

Gamificación, Feedback, Herramienta básica, Educación a distancia, Aprendizajes, Estrategia

Citation: ESCAMILLA, Regis Daisy \& MARTÍNEZ, Bahena Elizabeth. Gamification as a basic tool in distance education. Journal Computer Technology. 2020. 4-12:17-23.

\footnotetext{
* Correspondence to the author (Email: daxy3@ hotmail.com).

$\dagger$ Researcher contributing as first author.
} 


\section{Introduction}

There is something about games that we must not forget: they amuse us. The playful attitude offers an opportunity to increase participation, build loyalty, promote learning, communicate in a different way, solve problems, impact as a way to raise awareness and empower (Quotes: Games and gamification, 2020)

We are immersed in a global stage where all paradigms have to be modified, proposing new working methods that allow us to continue with our activities efficiently and effectively, trying to be as much or more productive than a few months ago, where tools Technological techniques give us the guideline to be able to combine all the knowledge in one place and thus be able to fulfill our teaching work; so meaningful in these changing times and so full of expectations.

Previously, the elements that made up "Traditional Education" included a classroom, a responsible teacher or instructor, books and books and other materials that we could access physically to make inquiries, all processes were based on reading and memorization and were guided by the instructor, who decided what to do, with what, how and in how much time. The games were only part of the recreation space and were sometimes also supervised by adults who set the tone to indicate how it should be played.

The most conservative position indicates that it cannot be instructed or trained without being followed to the letter, but as time goes by, we find ourselves in the need to think about expanding our preconceptions and taking away the idea that mature people, first comply and are sure of what they must carry out in order to ensure really meaningful knowledge.

This article will show the importance of the game as a fundamental part of current teaching-learning processes, which allows students to apply the knowledge of a specific topic or area, in a fun and sometimes competitive way, forcing themselves to answer Against the clock or against other colleagues, in healthy fights where the most important motivation will be to put into practice what has been understood.
Some digital tools are shown that have the game as a focal point as a fundamental part of the acquisition of knowledge, which at present is of great support for the teaching area that sees how the topics and the review can be intrinsically involved and obtain satisfactory results; Taking these procedures to a higher education level has shown that they are also of great impact and this is favorable in all areas of instruction.

The central hypothesis that is handled lies in the fact of demonstrating that, if gamification elements are included in the topics and adaptations to the study plans, they will allow to encourage students to generate new cognitive processes to know, investigate and empathically expand new ways to treat the information that is being imparted to them, so that the level of understanding will increase, also strengthening empathy, teamwork and cooperation.

The contents that are included will allow students to show their playful side and encourage research processes that motivate them to carry out the activities proposed in a specific application, giving their opinion, drawing, discovering and even guessing the answers to show the percentage of understanding about contents seen "normal" in classrooms.

\section{Gamification: What is it?}

Gamification can be defined as a technique that allows the inclusion of games in the educational field, in order to allow an improvement in the absorption of knowledge or processes shown in the classroom, to increase skills, actions that are carried out or increase the percentage perception of what has been learned.

It is based on playful processes (which are strategies designed to generate environments that facilitate the integration of students from the participation of different kinds of games); that encourage the learner to actively participate in activities that will allow them to show progress in the level of knowledge, immediately after a lesson or as a review at the end of a specific unit or topic. 
According to psychology, the processes that go hand in hand with the playful part allow the human being to be able to express feelings and attitudes that lead him to develop in an integral way and goes hand in hand with the emission of enjoyment, enjoyment, pleasure and satisfaction of instinctive demands, hence it is of great impact to allow the incorporation of gamification activities as an important complement in the application of knowledge.

\section{Types and examples of gamification}

Some virtual tools for gamification in classrooms are:

EDUCAPLAY. It allows the creation of activities focused on education, it is very easy to use and allows the incorporation of these contents to the educational platforms that we are using, it has free service options and it also allows the use of different contents that are active on the Internet.
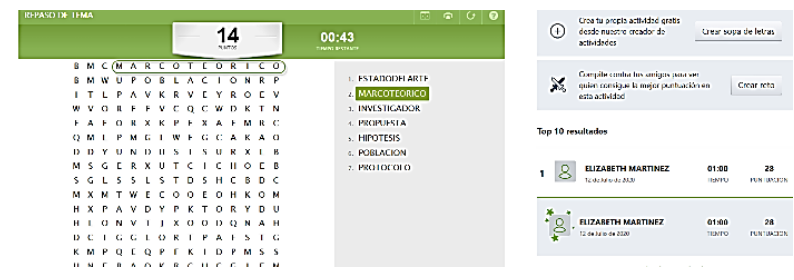

Figure 1 Educaplay Crossword resource Source: (Bahena, Educaplay, 2020)

- $\quad$ GENIALLY. It allows creating interactive content, anyone can use it since the development of activities can be generated by anyone who has an active session, manages free content and premium content that gives access to more complete tools and allows content to be downloaded to be used on any platform or digital tool.
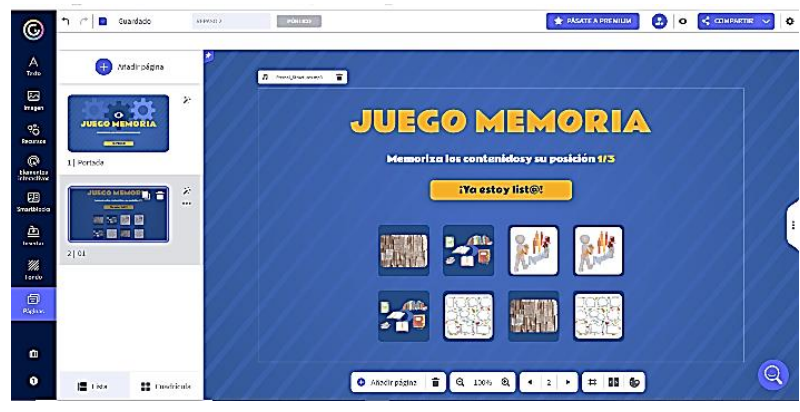

Figure 2 Genially Memory Game Resource Source: (Bahena, Genially, 2020)
GOCONQR. It is a very complete educational tool that allows you to adapt content to various activities, it has the disadvantage that the free version generates a large number of ads that can be very cumbersome for the user.

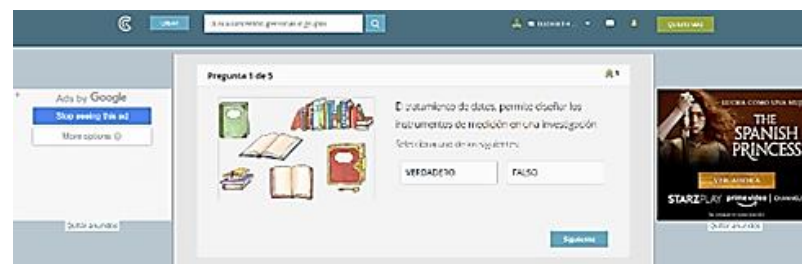

Figure 3 Goconqr Resource Review Source: (Bahena, Goconqr, 2020)

- PADLET. It is a digital platform that allows the creation of collaborative murals, offering the possibility of building spaces where multimedia resources can be presented, be it videos, audio, photos or documents; These resources are integrated as sticky notes, just as they were "reminder notes".

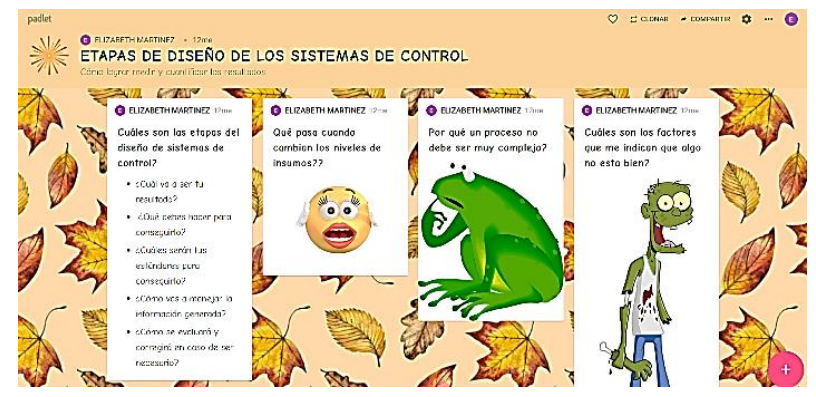

Figure 4 Padlet Opina Resource

Source: (Bahena, Padlet, 2019)

MOODLE. Despite being an educational platform by itself, Moodle allows adding gamification options to its resources, such as review questions, crosswords, hot potatoes, etc..

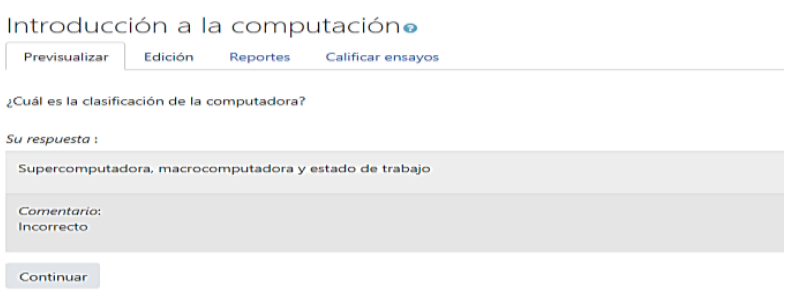

Figure 5 Moodle Resource Question Source: (Regis, 2019) 
As we can see, there is a great variety of digital options that offer us an unlimited variety of content that we can easily adapt to the subjects we handle semester by semester

\section{Relationship of gamification and Higher Education}

At present, a problem is experienced worldwide that has generated a significant number of challenges to allow continuing with the usual activities without reducing the quality or the completion times not increasing; A problem that arises in education is that, in addition to having to encourage students to attend their classes virtually, the level of interest in the student is maintained so that further training in the academic aspect is guaranteed, regardless of the educational level in which it is located.

Derived from this, procedures must be implemented that lead us to make use of virtual tools that allow complementing activities inside and outside all virtual classrooms, that is, looking for options so that teachers not only dedicate themselves to showing academic topics and content, but also that in addition, it can be encouraged in a fun and interesting way from activities that allow them to continue forming their knowledge.

For this, it is important to train teachers first so that they can include the use of cuttingedge technologies and tools within the content.

Now, we must also take into account that the requirements and needs in higher education are different from the other educational levels, they are changing and depend on the requests of the area professional, for which institutional governments must focus a large part of the resources that are assigned to the improvement of technological equipment within institutions.

The student, on the other hand, is responsible for forming knowledge processes that allow generating responses to the required requests, many times that go hand in hand with problems in their working life; This could be a coadjuvant in these procedures and give a break in the activities solely focused on knowledge, knowledge ... knowledge.

\section{Impact of gamification on current education}

The research was focused on students of a higher education institute (IES), where currently three distance engineering careers are taught and from which one subject of each career was taken as a sample, giving preference to theoretical subjects, since they are subjects in which the student's attention must be attracted more, due to being distance study, and that sometimes it is more complicated for students to acquire significant knowledge due to the too much information that is provided, this is how it was used study and apply gamification strategies, within the designs and materials provided in the subjects.

For this research, a quantitative method and descriptive research design was carried out, which allows to know the assessment of the students before the strategy called gamification, that is, if knowledge has been acquired through games that will allow them to have meaningful learning same as apply throughout your career. The use of gamification as a teaching-learning strategy in theoretical subjects was applied as shown in the following figure 6 , where the sample taken with respect to careers, subject, number of students and semester is seen.

Gamification technical application sample

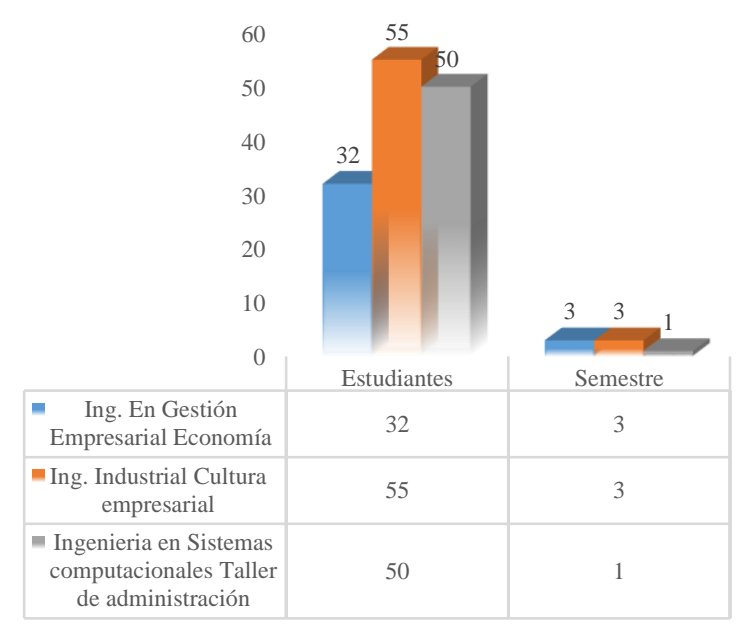

Figure 6 Initial sample

Once the sample was taken, work was done on gamification designs, only for one unit of each selected subject, this in order to observe the impact of the gamification tool within the subject, in comparison with the design and strategies that are commonly used in them. To carry out the design by implementing gamification, 
He resorted to certain platforms such as Genially, Educaplay, Goconqr, Padlet and those found in Moodle, the latter being the base platform for the design and support of the subjects that make up distance careers, the following figures show some examples of used gamification.

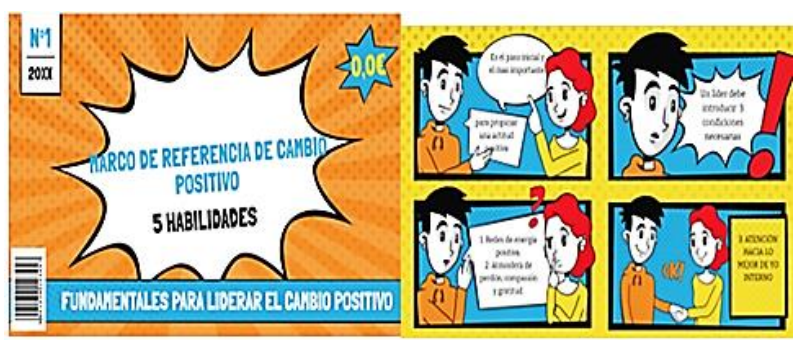

Figure 7 BookCreator example

In Figure 7, it shows an example using Genially, where a short topic is explained as a comic strip.

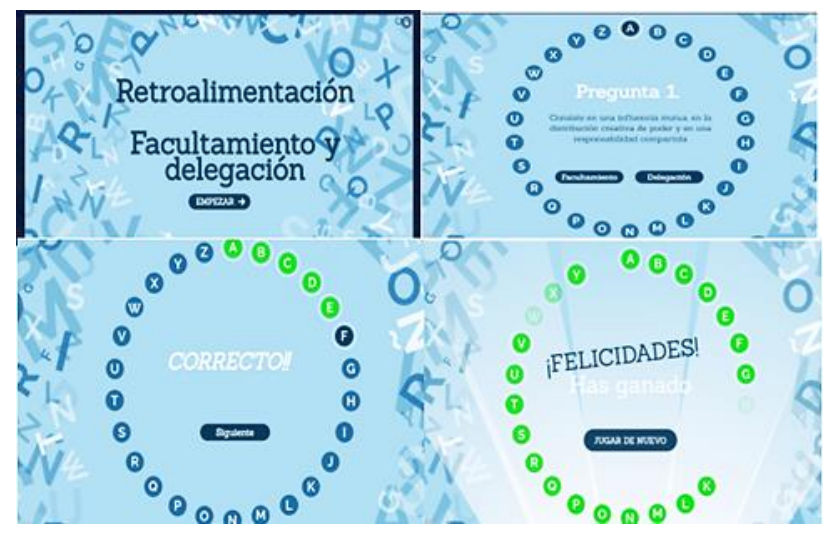

Figure 8 Educaplay example

In figure 8, feedback is given in such a way that each letter provides a random question and is very appealing to students.

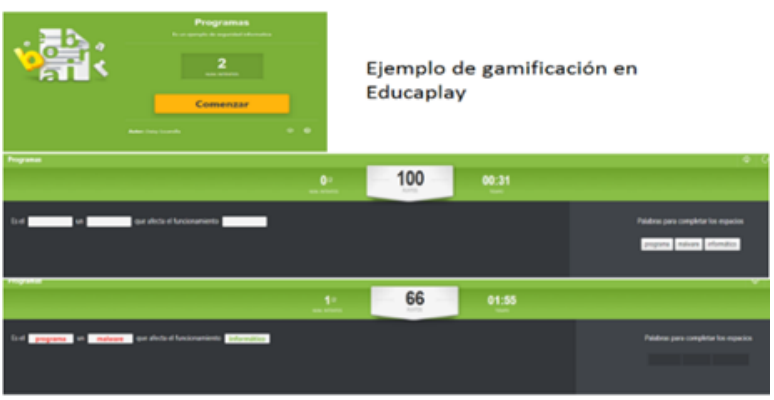

Figure 9 Educaplay example

In figure 9, another type of feedback is shown, but this with the help of videos, that is, in the sample of the resource it has a video and within this there are pauses where they are asked questions in such a way that makes the participant more student.
It is worth mentioning that, in the IES, three evaluation stages are carried out, therefore, to make a comparison of the traditional model with gamification tools, it was decided to apply the latter in the second evaluation, to evaluate if gamification is a basic tool in distance education.

Once counting on this, they began to apply satisfaction questionnaires to the students about the learning game tools that they visualized in the matter and another questionnaire to the facilitating teachers, to see the comparison of evaluation and impact that these tools had had. taking what is shown below.

In figure 10 , the satisfaction of the student is shown, which is seen as a favorable result, since $85 \%$ of them mention that they liked this way of learning and the topics of the unit were clear.

Evaluation from the point of view of the student

\begin{tabular}{|c|c|c|c|}
\hline \multicolumn{2}{|c|}{$\begin{array}{l}\text { What did you think about the } \\
\text { design of unit two of the topics } \\
\text { of your subject? }\end{array}$} & \multicolumn{2}{|c|}{$\begin{array}{l}\text { Do you think that you } \\
\text { understood the topic seen? }\end{array}$} \\
\hline Good & 85 & $85-100 \%$ & 80 \\
\hline Regular & 10 & $70-84 \%$ & 15 \\
\hline $\mathrm{Bad}$ & 5 & Less than $69 \%$ & 5 \\
\hline \multicolumn{2}{|c|}{ Unit two has fun. } & & \\
\hline Good & 90 & & \\
\hline Regular & 10 & & \\
\hline $\mathrm{Bad}$ & 0 & & \\
\hline
\end{tabular}

Evaluation from the point of view of the student

What did you think about the design of unit two of the topics of your subject?

100

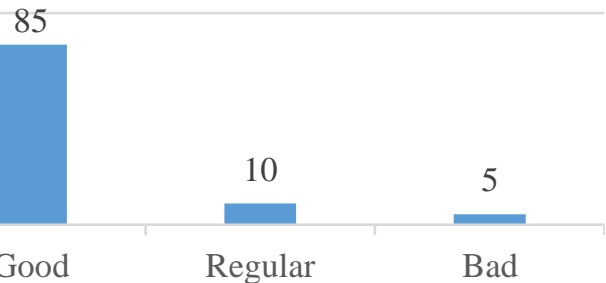

100

Do you think that you understood the topic seen?

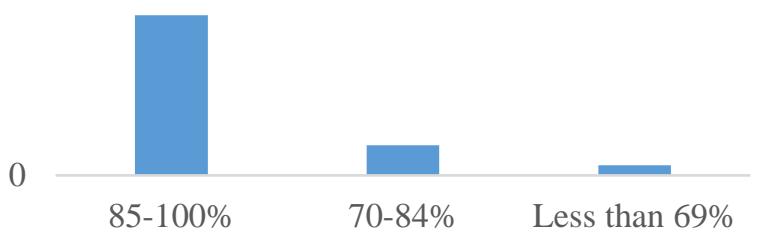

Unit two has fun

100

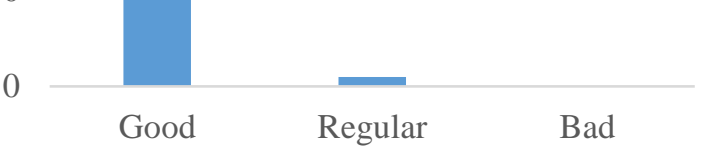

Figure 10 Student satisfaction 


\begin{tabular}{|l|r|l|r|}
\hline \multicolumn{4}{|c|}{ Evaluation questions } \\
\hline $\begin{array}{l}\text { How do you assess the student's } \\
\text { learning in unit 2? }\end{array}$ & \multicolumn{2}{l|}{$\begin{array}{l}\text { What percentage of failure rate } \\
\text { did you have in Unit 2? }\end{array}$} \\
\hline Good & 75 & $85-100 \%$ & 0 \\
\hline Regular & 22 & $70-84 \%$ & 4 \\
\hline Bad & 3 & Less than 69\% & Compared to unit 1, do you think \\
\hline $\begin{array}{l}\text { What percentage of participation } \\
\text { did you have in unit 2? }\end{array}$ & $\begin{array}{l}\text { you had more student } \\
\text { participation in unit 2? }\end{array}$ \\
\hline $85-100 \%$ & 90 & Yes & 98 \\
\hline $70-84 \%$ & 10 & No & 2 \\
\hline Less than 69\% & 0 & & \\
\hline
\end{tabular}

Evaluation of the gamification unit, by the facilitator teacher How do you assess the student's learning in unit 2?

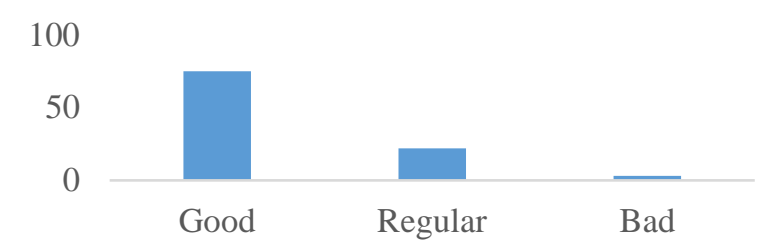

What percentage of failure rate did you have in Unit 2 ?

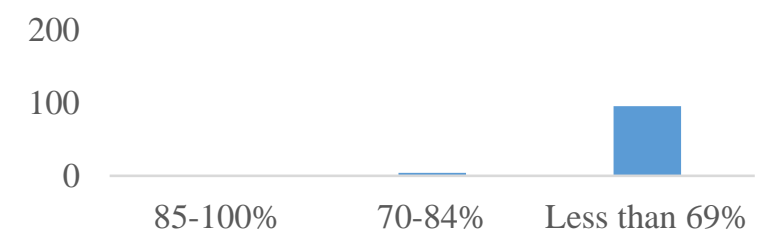

What percentage of participation did you have in unit 2 ?

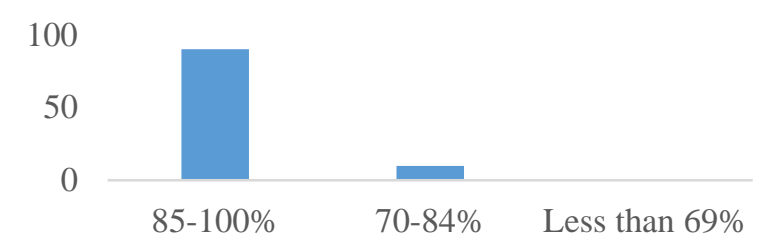

Compared to unit 1 , do you think you had more student participation in unit 2?

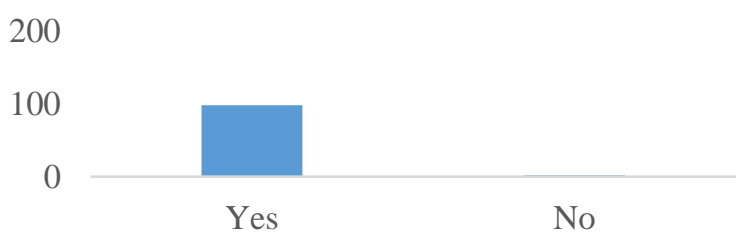

Figure 11 Teacher evaluation on gamification

In Figure 11, the survey carried out to the facilitating teachers is shown, making a comparison of evaluations obtained in the first part (traditional distance career strategies) and second part (gamification strategy), in which it can be determined that there was an improvement in grades and, above all, in the learning that students acquired, since there was more participation on the part from them.
In general, based on the survey carried out to the teacher and the student, a great agreement is observed, in the aspect that when using gamification tools for the subject in the second unit, there was a high approval rate and greater participation of the students.

\section{Results}

With this research it has been found that for students who study distance careers, the design with the use of gamification strategies is more attractive, since, more than $85 \%$ consider that the subject seen understands it more, and they find it more fun type of learning; on the other hand, the teacher-facilitators had greater participation in their subject by the students, and less failure rate compared to the evaluations they had in the first unit, which shows more motivation on the part of the students in the participation of the subject viewed.

\section{Conclusions}

Currently there are various strategies that can be applied as part of the teaching-learning process for students with distance modality, in this case the research that was carried out and which turned to verify the importance of play as a fundamental part of current teaching processes. learning, allows detecting that gamification can be beneficial to implement it in higher-level students, who having a different way of acquiring knowledge was motivating and resulted in better grades in the second unit of their subject.

On the other hand, it shows that the gamification elements in the topics that make up the unit and adaptations to the study plans will allow students to be encouraged to generate new cognitive processes to know, investigate and empathically expand new ways of treating the information that is teaching them, increasing the level of understanding and further strengthening the strategies that are already contemplated in the design of each subject.

\section{References}

Arroyo, C. (15 de julio de 2018). Blogelpaís.com. Obtenido de http://blogs.elpais.com/ayuda-alestudiante/2013/12/la-neuroeducaciondemuestra-que-emocion-y-conocimiento-vanjuntos.html

ESCAMILLA, Regis Daisy \& MARTÍNEZ, Bahena Elizabeth. Gamification as a basic tool in distance education. Journal Computer Technology. 2020 
Bahena, E. M. (Noviembre de 2019). Padlet. Obtenido de

https://padlet.com/azuri9404/azjkvgkrrpbm

Bahena, E. M. (26 de Octubre de 2020). Educaplay. Obtenido

de https://es.educaplay.com/

Bahena, E. M. (26 de Octubre de 2020). Genially. Obtenido de https://app.genial.ly/dashboard

Bahena, E. M. (26 de Octubre de 2020). Goconqr. Obtenido de https://www.goconqr.com/quiz/24247329/repas o-2-?locale=es

BCN. (s.f.). BCN (plataforma tecnológica interactiva). Recuperado el 15 de 06 de 2011, de http://bcn.gob.ni/estadisticas/sic_em50a/

Citas: Juegos y gamificación. (26 de Octubre de 2020). Obtenido de https://anaordas.com/10citas-sobre-juegos-y-gamificacion/

Coleman, G. (07 de 11 de 2019). lampadia.com. Obtenido de www.lampadia.com

Google imagenes. (10 de julio de 2018). Obtenido de https://www.google.com.mx/search?q=imagene $\mathrm{s}+\mathrm{de}+$ aplicaciones+web\&tbm=isch\&source

Innovación educativa. (2019). Obtenido de https://www.ipn.mx/assets/files/innovacion/doc s/Innovacion-Educativa-80/Retos-deingenieria-enfoque-educativo.pdf

Regis, D. E. (Octubre de 2019). Moodle. Obtenido https://tescionline.org/course/view.php?id=222 $1 \&$ section $=2$ 